\title{
SALOMÃO, Rommy. A formação continuada de professores alfabetizadores: do Pró-Letramento ao PNAIC. 2014. 117 f. Dissertação (Mestrado em Educação) - Universidade Estadual de Ponta Grossa, Ponta Grossa, 2014.
}

\begin{abstract}
A presente pesquisa tem como objeto de estudo as políticas educacionais voltadas à formação continuada de professores dos anos iniciais do Ensino Fundamental. Este estudo analisa o processo de implantação e implementação das ações desenvolvidas pelo Governo Federal no sentido de contribuir para a superação das dificuldades dos professores alfabetizadores no processo de ensino e de aprendizagem. Considerando o contexto em que os professores se encontram, em relação aos programas de formação continuada mantidos pelo Governo Federal, o desenvolvimento desta pesquisa teve como foco principal a análise do processo de implantação do Pacto Nacional pela Alfabetização na Idade Certa, que teve início com a realização dos trabalhos de formação continuada com os professores da rede pública de ensino no município de Ponta Grossa no ano de 2013. Assim sendo, a presente pesquisa tem como norte a seguinte problemática: Como se deu o processo de implantação do Pacto Nacional pela Alfabetização na Idade Certa a partir da consolidação do Programa Pró-Letramento? Para atender a questão levantada, definiu-se como objetivos específicos: contextualizar a constituição das políticas públicas educacionais para a formação continuada dos professores a partir da década de 1990 no Brasil; identificar os aspectos do Programa Pró-Letramento que foram determinantes para a implantação do PNAIC; identificar a proposta de implantação do Pacto Nacional pela Alfabetização na Idade Certa para a formação continuada dos professores alfabetizadores. No sentido de compreender as dimensões que perpassam a formação continuada de professores, partiu-se da elaboração de um quadro teórico-metodológico o qual permite compreender o contexto histórico e seus determinantes. Para tanto, o eixo teórico-metodológico expressa-se por meio do materialismo histórico-dialético que concebe a realidade a partir da apreensão de suas contradições na sua totalidade. Os procedimentos metodológicos adotados foram pautados na pesquisa teórica bibliográfica das principais produções que abordam a temática estudada. O levantamento bibliográfico foi utilizado como aporte teórico para fundamentar o estudo da temática e teve, como base, autores que discutem sobre a reforma do Estado e as políticas educacionais. A pesquisa documental utilizou fontes primárias (legislação) que possibilitou a compreensão do processo de consolidação do Programa Pró-Letramento no âmbito das políticas educacionais para a formação continuada de professores dos anos iniciais, bem como o processo de implantação
\end{abstract}


do Pacto Nacional pela Alfabetização na Idade Certa. Concluiu-se que a formação continuada de professores oportuniza aos atores a formação e a atualização de conhecimentos que estão em constante transformação na sociedade, fazendo com que a atividade educativa promova a emancipação humana, contribuindo para que o indivíduo tenha participação efetiva na sociedade ao mesmo tempo que transforma sua própria realidade. 